\title{
Intervals between multiple ovulations in PMSG-treated and untreated ewes and the relationship between ovulation and oestrus
}

\author{
D. Whyman* $\ddagger$, D. L. Johnson $\dagger$, T. W. Knight* and R. W. Moore* \\ ${ }^{*}$ Whatawhata Hill Country Research Station and $\dagger$ Ruakura Agricultural Research Centre, \\ Ministry of Agriculture and Fisheries, Private Bag, Hamilton, New Zealand
}

\begin{abstract}
Summary. The timing of ovulations in 42 PMSG-treated ewes was determined by repeated endoscopy. The first ovulation occurred at a median time of $23.6 \pm 0.5$ (s.e.m.) $\mathrm{h}$ after the onset of oestrus. The median interval between first and second ovulations was less than $1 \mathrm{~h}$, and that between first and last ovulations was approximately $6 \mathrm{~h}$.

In 59 untreated ewes, probit regression analysis was applied to the number of ovulations which were found by endoscopy to have occurred by 23,25 and $27 \mathrm{~h}$ after the onset of oestrus. The median time of first ovulation was $25.5 \pm 0.5 \mathrm{~h}$ after the onset of oestrus, this interval being similar in single- and twin-ovulating ewes. The median interval between twin ovulations was $1.2 \pm 0.6 \mathrm{~h}$. Ovulation occurred after the end of oestrus in at least $75 \%$ of ewes.
\end{abstract}

\section{Introduction}

Evidence for the existence of a direct ram effect on the multiple birth rate of the ewes to which they are mated has been reviewed by Turner (1969) and Bradford (1972). Further support for this effect has been obtained from single-sire mating groups in a high fertility New Zealand Romney flock (Hight, Gibson, Wilson \& Guy, 1975), and certain semen traits have been found to be correlated with the multiple birth rate of rams from this flock (Moore \& Whyman, 1977). In an artificial insemination experiment comparing rams from lines selected for and against multiple births (Clarke, 1972), it was found that semen from high-fertility rams fertilized more multiple-ovulating ewes than did semen from low-fertility rams (R. W. Moore \& D. Whyman, unpublished). If there is a marked asynchrony of multiple ovulations, the ram effect could be explained by differences in the viability of spermatozoa within the ewe's reproductive tract or the frequency or duration of mating activity, because each of these variables could influence the chance of more than one egg being fertilized.

The primary objectives of the present study were to investigate the interval between naturally occurring twin ovulations and to relate the time of first ovulation to the beginning and end of oestrus. Since the incidence of twin ovulations was expected to be low, a preliminary experiment was conducted with ewes given PMSG to increase the multiple ovulation rate and the appropriate times for the minimum number (3) of endoscopies required for probit regression analysis were determined.

\section{Materials and Methods}

Two experiments were carried out in separate years during the middle of the breeding season (May).

$\ddagger$ Present address: South Pacific Commission, P.O. Box D.5, Noumea Cedex, New Caledonia. 


\section{Experiment 1}

Oestrus was synchronized in two groups of ewes by using intravaginal sponges, impregnated with $30 \mathrm{mg}$ Cronolone (Searle), for 14 days. An intramuscular injection of PMSG (Gonadotrophon: Paynes \& Byrne) was given 14 days after sponge removal. Vasectomized rams were added to the ewe flock in a ratio of 1 ram to 7 ewes before the second oestrus after sponge removal. The onset of oestrus was detected in a proportion of the ewes by continuous observation of mating activity in yards during a period of $7-11 \mathrm{~h}$. The ewes were then removed and the ovaries were observed by repeated endoscopy under local anaesthesia following sedation by the injection of $10 \mathrm{mg}$ acetylpromazine (Boots). Endoscopy began $20 \mathrm{~h}$ after the onset of oestrus, and the final ovulation rate was determined from the number of corpora lutea (CL) present at autopsy 3 days after oestrus.

The first group comprised 24 Romney and 4 Border Leicester $\times$ Romney ewes injected with 1200 i.u. PMSG. Endoscopy was repeated until all ovulatory activity had ended, as judged by the lack of large growing follicles. Most (153) of the successive observations were made at intervals of $1-1 \frac{1}{2} h$ but 13 of the intervals were up to $3 \frac{1}{2} h$ because of technical delays. The maximum period of observation was $13 \mathrm{~h}$.

In the second group of ewes the PMSG dose was reduced to 1000 i.u. because the number of ovulations was excessive in many ewes of the first group. Endoscopy, performed on 14 Romney ewes, was continued for at least $20 \mathrm{~h}$ at intervals of $1 \frac{1}{2}-3 \mathrm{~h}$, with a further observation after $9 \mathrm{~h}$. At this time, follicles which appeared to be close to ovulation were still present in 5 of the ewes, and final observation of these ewes was made 17-19 h later.

The intervals between successive endoscopies varied randomly within each group of ewes.

\section{Experiment 2}

The ewes in this experiment were of the Romney, Drysdale, Border Leicester $\times$ Romney, Dorset $\times$ Romney, Cheviot and Perendale breeds. Oestrus was synchronized in two groups of ewes and the onset of the second oestrus after sponge removal was monitored as in Exp. 1. Endoscopy was performed on 25 ewes in the first group and 34 in the second. Two vasectomized rams remained with each group of ewes and observations of mating activity were resumed approximately $21 \mathrm{~h}$ after the onset of oestrus. A restricted number of endoscopies was planned for this experiment so that any possible stress effect of the technique on the timing of ovulations was limited and the sedative was omitted for the same reason. Three times of endoscopy were chosen, predicted from the results of Exp. 1 to give parallel probit regressions of the cumulative number of ewes ovulating on time for first and second ovulations. These times were 23, 25 and $27 \mathrm{~h}$ after the onset of oestrus. The ewes were killed 2-3 days after oestrus and the ovaries examined to determine the final number of ovulations.

Large follicles present at the final endoscopy and at autopsy were counted and their sizes were estimated.

\section{Statistical analysis}

Interval from onset of oestrus to first ovulation. Probit regression techniques are often used to fit a relationship between the percentage of ewes having ovulated and the time elapsed since the onset of oestrus. As is suitable for this type of analysis we assume that the probability distribution of the time to first ovulation, transformed to the logarithmic scale, is normal. Thus, if $F(t)$ denotes the probability that a ewe has ovulated by time $t$ after the onset of oestrus, then

$$
F(t)=\frac{1}{\sigma \sqrt{2} \pi} \int_{-\infty}^{\ln t} \exp \left[-\frac{1}{2}\left(\frac{x-\mu}{\sigma}\right)^{2}\right] d x
$$


where $\mu$ and $\sigma$ are the mean and standard deviation of the distribution. Probit analysis (Finney, 1952) is not appropriate for this work since the history of one group of ewes is followed from the onset of oestrus and so the observed percentage having ovulated is monotonic, increasing with time, thus inducing a structure of correlated errors for the probit regression.

Let $N$ be the total number of ewes that ovulate and let $n\left(t_{i}\right)$ be the number observed to have ovulated when endoscopy is carried out at time $t_{i}(i=1, \ldots m)$. If we set $t_{o}=0$ and $t_{m+1}=\infty$ then $n\left(t_{o}\right)=0$ and $n\left(t_{m+1}\right)=N$ while $F\left(t_{o}\right)=0$ and $F\left(t_{m+1}\right)=1$. By considering the number of ewes ovulating during the intervals $\left\{\left(t_{i}, t_{i+1}\right)\right\}_{i=0 . . . m}$ the likelihood of obtaining the sample $\left\{n\left(t_{i}\right), N\right\}_{i=1, \ldots m}$ is given by

$$
\prod_{i=0}^{m}\left[F\left(t_{i+1}\right)-F\left(t_{i}\right)\right] n\left(t_{i+1}\right)-n\left(t_{i}\right)
$$

As in probit analysis the maximum likelihood equations are solved by an iterative procedure to obtain estimates of $\mu$ and $\sigma, \mu$ being the mean interval to first ovulation on the logarithmic scale. Thus $\mathrm{e}^{\mu}$ is the median time to first ovulation.

Interval between twin ovulations. The following analysis was applied to data in Exp. 2. For twin ovulating ewes, $n_{1}(t)$ is defined as the number of ewes having at least one ovulation, and $\mathrm{n}_{2}(\mathrm{t})$ is the number having ovulated twice, by time $\mathrm{t}$. The latter can be transformed thus:

$$
\mathrm{n}_{2}(\mathrm{t})=\mathrm{n}_{1}(\mathrm{t}-\tau)
$$

where $\tau$ is the interval between twin ovulations. Hence $n_{2}(t)$ is the number of ewes with at least one ovulation by time $t-\tau$.

As above we assume that endoscopy is carried out at times $t_{1}(i=1, \ldots m)$. We have similarly, $\mathrm{n}_{1}\left(\mathrm{t}_{0}\right)=\mathrm{n}_{2}\left(\mathrm{t}_{0}\right)=0$ and $\mathrm{n}_{1}\left(\mathrm{t}_{\mathrm{m}+1}\right)=\mathrm{n}_{2}\left(\mathrm{t}_{\mathrm{m}+1}\right)=\mathrm{N}_{2}$ where $\mathrm{N}_{2}$ is the total number of twin ovulating ewes. If $\tau$ satisfies the inequalities $0 \leq \tau \leq t_{1}-t_{i-1}(i=1, \ldots m)$, that is, if $n_{2}\left(t_{i}\right) \geq$ $n_{1}\left(t_{1-1}\right)(i=1, \ldots m)$, then by considering the distribution of the time to first ovulation, as above, the likelihood of obtaining the sample $\left\{n_{1}\left(t_{i}\right), n_{2}\left(t_{1}\right), N_{2}\right\}_{1=1, \ldots m}$ is given by

$$
\prod_{i=0}^{m}\left[F\left(t_{i+1}-\tau\right)-F\left(t_{1}\right)\right]^{n_{2}\left(t_{i+1}\right)-n_{1}\left(t_{i}\right)}\left[F\left(t_{i+1}\right)-F\left(t_{1+1}-\tau\right)\right]^{n_{1}\left(t_{i+1}\right)-n_{2}\left(t_{i+1}\right)}
$$

This likelihood is a function of three parameters $\mu, \sigma$ and $\tau$ and the maximum likelihood estimates are again found by iterative solution.

\section{Results}

\section{PMSG-treated ewes (Exp. 1)}

The peak onset of the second oestrus occurred 18 days after sponge removal, and the total number of ovulations per ewe varied between 1 and 29 in the first group of ewes and between 2 and 6 in the second group. Of the 42 ewes, 21 had more than 5 ovulations. The number of ovulations recorded at endoscopy was accurate in only 2 of these ewes, and in all but one of the remainder the number of ovulations observed was less than the number of CL present at autopsy. Accurate counts of ovulations were made in 6 of the other 21 ewes which had 5 or less ovulations: in 4 the ovulation rate was underestimated and in the other 2 there were more ovulations recorded at endoscopy than at autopsy. When the ovaries were observed at autopsy, surface counts of CL sometimes did not correspond to the actual number confirmed by sectioning the ovaries. The data have been interpreted on the assumption that follicles which ovulated did so at the ovarian surface and were visible at endoscopy.

The probit regression obtained from the cumulative distribution of the time of first recorded 


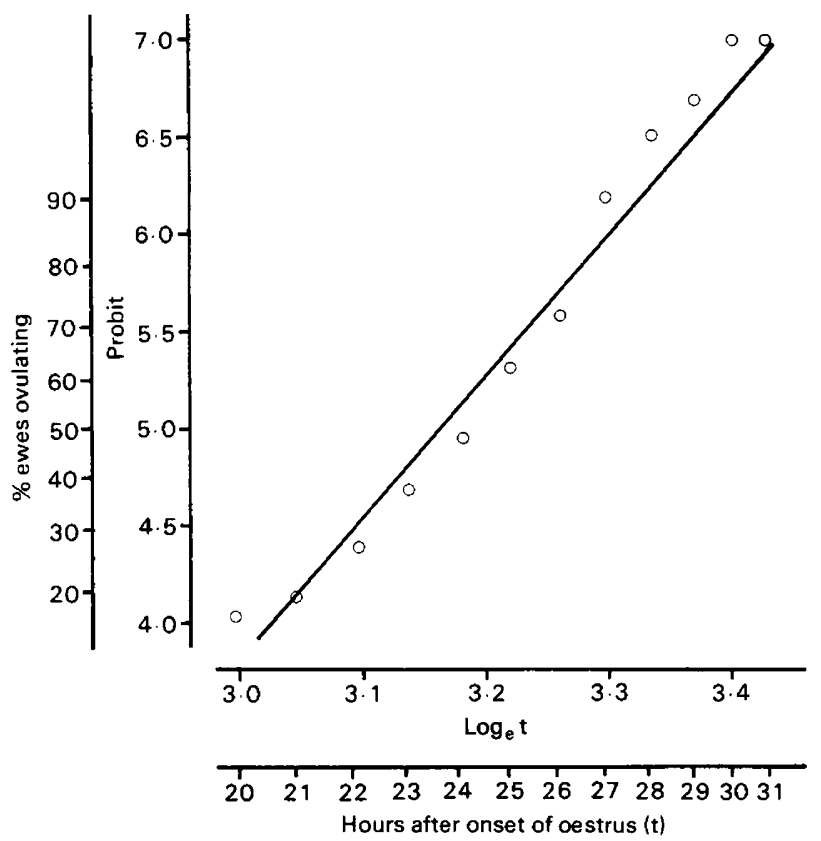

Text-fig. 1. Probit transformation of the percentage of PMSG-treated ewes having ovulated by various times after the onset of oestrus.

ovulation is shown in Text-fig. 1. Ovulation had already occurred in 7 ewes by the time of the first endoscopy $20 \mathrm{~h}$ after the onset of oestrus, whereas the longest interval to first ovulation was $32 \mathrm{~h}$. The median interval from oestrus to the first ovulation was estimated to be $23.6 \pm 0.5 \mathrm{~h}$.

Estimates of the interval between first and second ovulations, and that between the first and last ovulations, are summarized in Table 1. Reliable information on these intervals was not available from all of the ewes, and the data shown are derived only from those ewes in which the

Table 1. Intervals between ovulations in PMSG-treated ewes (Exp. 1), and the number of ewes in which the intervals are known to be shorter or longer than various stated times

\begin{tabular}{cccc}
\hline Interval & $\begin{array}{c}\text { Length of interval } \\
\text { (hours) }\end{array}$ & $\begin{array}{c}\text { No. of ewes with } \\
\text { longer interval }\end{array}$ & $\begin{array}{c}\text { No. (\%) of ewes with } \\
\text { shorter interval }\end{array}$ \\
\hline 1st to 2nd ovulation & 1 & 4 & $13(76)$ \\
& 2 & 3 & $22(88)$ \\
& 3 & 3 & $22(88)$ \\
& 4 & 2 & $26(93)$ \\
1st to last ovulation & 5 & 1 & $27(96)$ \\
& 6 & 0 & $29(100)$ \\
& 1 & 29 & $1(3)$ \\
& 2 & 17 & $4(16)$ \\
& 3 & 11 & $4(19)$ \\
& 4 & 10 & $5(31)$ \\
& 5 & 8 & $5(33)$ \\
& 6 & 4 & $7(47)$ \\
& 8 & 3 & $10(71)$ \\
& 10 & 2 & $11(79)$ \\
& 12 & 1 & $13(93)$ \\
\hline
\end{tabular}


interval under consideration was definitely longer or shorter than the various times indicated. The variation in number of ewes included in each assessment resulted from the different intervals between successive endoscopies and from the known inaccuracies in recorded ovulations. The necessary omissions were, however, evenly distributed throughout the data.

By reference to the percentages of ewes in which the intervals were shorter than the stated times it can be concluded that the median interval between first and second ovulations was less than $1 \mathrm{~h}$, and that between first and last ovulations was approximately $6 \mathrm{~h}$. No relationship was found between these intervals and the total number of ovulations.

\section{Untreated ewes (Exp. 2)}

Ewes in this experiment exhibited their second oestrus 18-19 days after sponge removal. The duration of oestrus was less than $21 \mathrm{~h}$ in 48 ewes, $21-23 \mathrm{~h}$ in 10 ewes, and longer than $27 \mathrm{~h}$ in 1 ewe. There was no relationship between the length of oestrus and the number of ovulations.

One of the ewes did not ovulate and was found at autopsy to have a single luteinized follicle. Another ewe had 3 ovulations, all of which occurred before the first endoscopy. Of the remaining ewes, 36 had a single ovulation and 21 were twin-ovulators (Table 2).

Table 2. Ovulations recorded at endoscopy in single- $(N=36)$ and twin- $(N=21)$ ovulating ewes (Exp. 2)

\begin{tabular}{|c|c|c|c|c|c|c|c|}
\hline \multirow[b]{3}{*}{$\begin{array}{l}\text { Time after } \\
\text { onset of } \\
\text { oestrus (h) }\end{array}$} & \multirow{3}{*}{$\frac{\text { Single ovulators }}{\begin{array}{c}\text { No. of ewes } \\
\text { ovulating }\end{array}}$} & \multirow{2}{*}{\multicolumn{2}{|c|}{ Twin ovulators }} & \multicolumn{4}{|c|}{$\%$ ewes ovulating } \\
\hline & & & & \multirow[b]{2}{*}{$\begin{array}{c}\text { Single } \\
\text { ovulators }\end{array}$} & \multirow[b]{2}{*}{$\begin{array}{l}\text { Single and twin } \\
\text { 1st ovulation }\end{array}$} & \multicolumn{2}{|c|}{ Twin ovulators } \\
\hline & & $\begin{array}{l}\text { No. of ewes } \\
\text { ovulating }\end{array}$ & $\begin{array}{l}\text { No. of ewes } \\
\text { with } 2 \\
\text { ovulations }\end{array}$ & & & $\begin{array}{c}1 \text { st } \\
\text { ovulation }\end{array}$ & $\begin{array}{c}\text { 2nd } \\
\text { ovulation }\end{array}$ \\
\hline 23 & 9 & 5 & 2 & 25 & 25 & 24 & 10 \\
\hline 25 & 14 & 6 & 5 & 39 & 35 & 29 & 24 \\
\hline 27 & 26 & 14 & 10 & 72 & 70 & 67 & 48 \\
\hline
\end{tabular}

The probit transformations of the percentages of single- and twin-ovulating ewes that had ovulated at the three times of endoscopy are shown in Text-fig. 2. Probit regressions were fitted to the first ovulation data for single- and twin-ovulating ewes. Since the regression equations were not significantly different, a probit regression was fitted to the combined data. From this analysis the median interval between the onset of oestrus and first ovulation, $e^{\mu}$, was $25.5 \pm 0.5$ $h$ and $\sigma$ was estimated to be $0.13 \pm 0.02$. In twin-ovulating ewes, the mean interval between ovulations, $\tau$, was $1.2 \pm 0.6 \mathrm{~h}$.

Ovulation occurred after the end of oestrus in at least $75 \%$ of ewes, including all 27 singleovulating and 17 multiple-ovulating ewes which ovulated later than $23 \mathrm{~h}$ after the onset of oestrus. In 15 of these ewes ( $25 \%$ of all ewes) the delay after oestrus exceeded $6 \mathrm{~h}$. It was possible to relate the time of ovulation to the end of oestrus in only 2 of the 15 ewes which had ovulated by the time of the first endoscopy: first ovulation occurred at least $4 \mathrm{~h}$ before, and earlier than $2 \mathrm{~h}$ after, the end of oestrus respectively.

Out of a total of 30 ewes in which ovulation was completed by the final endoscopy, 11 possessed at least one follicle of $6 \mathrm{~mm}$ diameter or larger. With the possible exception of one ewe, in which a single $10 \mathrm{~mm}$ follicle was present at endoscopy and at autopsy, these follicles all regressed within the 1-2 days before slaughter. Similar cystic follicles were found in another 2 ewes at autopsy; these follicles had developed after the final endoscopy. Follicular luteinization occurred in 3 ewes, including the ewe which did not ovulate.

The breed of ewe had no discernible effect on the timing of ovulation. 


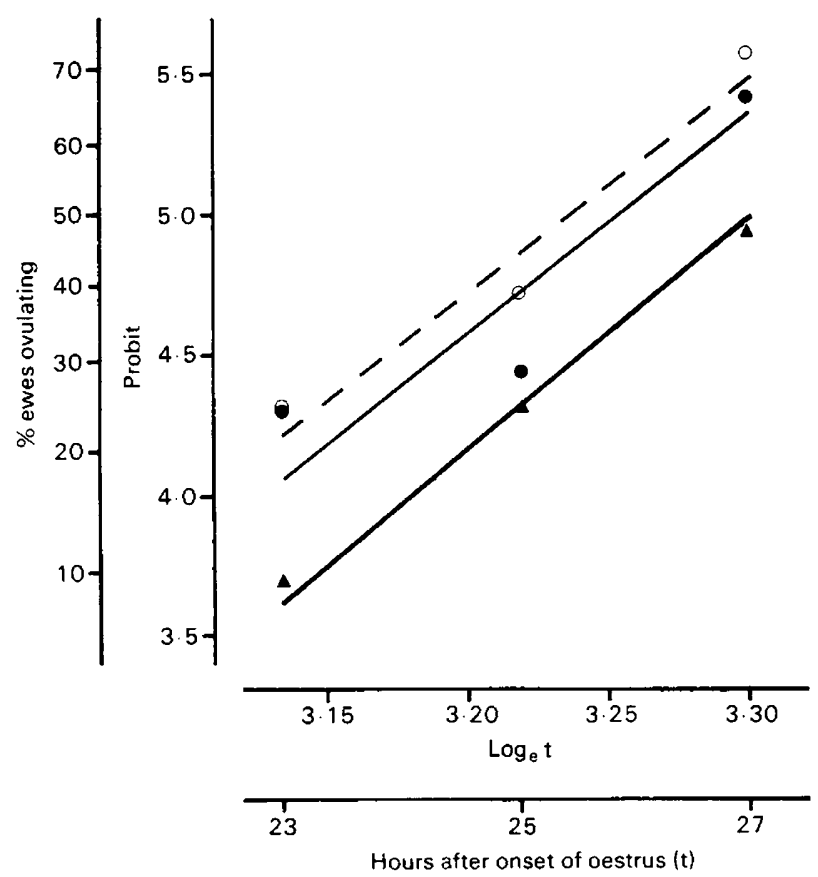

Text-fig. 2. Probit transformations of the percentage of untreated ewes with one or two ovulations at the three times of endoscopy (Exp. 2). The broken line is the regression on the log interval after the onset of oestrus, derived from both single $(O)$ and twin $(O)$ ovulating ewes. Continuous lines show regressions for first $(\boldsymbol{O})$ and second $(\boldsymbol{\Delta})$ ovulations in twin-ovulating ewes; the horizontal distance between these lines gives the estimate of the interval between twin ovulations.

\section{Discussion}

The median interval of $25.5 \mathrm{~h}$ between the onset of oestrus and ovulation in untreated ewes is similar to most reported estimates, $24-40 \mathrm{~h}$, obtained at natural oestrus or at the oestrus following progestagen withdrawal (Parsons, Hunter \& Rayner, 1967; Cognié, Mariana \& Thimonier, 1970; van der Westhuysen, van Niekerk \& Hunter, 1970; Holst \& Braden, 1972; Schindler \& Amir, 1972; Cumming et al., 1973; Boshoff, van Niekerk \& Morgenthal, 1973). The present study showed that in ewes treated with PMSG at a natural oestrus the timing of the first ovulation was similar, with a median interval of $23.6 \mathrm{~h}$ after the start of oestrus. Mean values obtained by Boshoff et al. (1973), Cognié et al. (1970) and Smith (1977) in ewes given PMSG at progestagen-sponge withdrawal are comparable, although Cognié et al. (1970) reported a bimodal distribution. Boshoff et al. (1973) showed that PMSG advanced the time of ovulation, but this was not confirmed by Cognie et al. (1970) or by Smith (1977). A direct assessment of the effect of PMSG was not possible in the present study.

Allowing continuous contact with rams, at least $75 \%$ of the untreated ewes ovulated after the end of oestrus, although at least one ewe ovulated before mating activity ceased. Many other workers (Zeltobrjuh \& Rak, 1964; Parsons et al., 1967; van der Westhuysen et al., 1970; Holst \& Braden, 1972; Schindler \& Amir, 1972; Cahill, Buckmaster, Cumming, Parr \& Williams, 1974) have also found the mean time of ovulation to be several hours after the end of oestrus, at least under conditions of continuous or frequent contact with rams, with a range generally including some ewes which ovulate whilst they are still sexually active. The present study substantiates the evidence against the contention of Quinlan \& Mare (1931) that the end of oestrus depends on rupture of the follicle. 
The interval of $1.2 \mathrm{~h}$ between first and second ovulations in normal twin-ovulating ewes in this study is comparable to the results of McKenzie \& Terrill (1937) who reported a mean interval of $1.7 \mathrm{~h}$. Some Russian workers recorded an interovulatory interval of up to $4 \mathrm{~h}$, whereas others estimated the interval to be as long as 10-15 h (see Lopyrin, 1971). Lopyrin suggested that the longer intervals quoted may be based on erroneous interpretation of the fate of large follicles which were frequently found to accompany ovulated follicles. Moore, Rowson \& Short (1960) reported the apparent formation of additional CL from large follicles present at the time of first ovulation, suggesting asynchrony of ovulations. Similar follicles were found by MacKenzie \& Edey (1975) to be capable of luteinization to form structures which could be confused with normal CL. In the present study, delayed ovulation of large follicles accompanying newly formed CL did not take place, although luteinization of unruptured follicles occurred in 3 ewes.

Quinlan \& Maré (1931), McKenzie \& Terrill (1937) and Schindler \& Amir (1972) have described the changes in appearance of ruptured follicles with time. Whilst these observations may be satisfactory in the case of normal ovulations, follicles ovulating in response to PMSG were found in the present study to vary considerably in size, surface appearance and morphology. Furthermore, the disagreement between the total number of CL and the number visible on the surface of the ovary in some cases casts doubt on the accuracy of estimates of PMSG-induced superovulation obtained without sectioning the ovaries. The number of ova recovered from the oviducts 3 days after superovulation sometimes exceeds the number of $\mathrm{CL}$ present at the ovarian surface (D. Whyman, unpublished).

A frequent cause of inaccuracies in recorded ovulations was the occurrence of ovulation in neighbouring follicles at points closely juxtaposed to each other. Such pairs of ovulations were difficult to distinguish from single ovulation sites. Conversely, single-ovulating follicles sometimes appeared to be double ovulation sites. Despite these difficulties it was possible to conclude that, as in untreated ewes, the delay between first and second ovulation was of short duration (less than $1 \mathrm{~h}$ ) after PMSG treatment, although it frequently took several hours for the completion of all ovulations.

The importance of asynchrony of multiple ovulations in accounting for observed differences among sires in the number of multiple births they produce (Turner, 1969; Bradford, 1972; Hight et al., 1975) is dependent on the length of time that spermatozoa remain in the oviducts and retain their capacity to penetrate and fertilize ova. This has been estimated to be a maximum of 24-48 $\mathrm{h}$ in the sheep (Green, 1947; Dauzier \& Wintenberger, 1952), although favourable conditions for fertilization after natural mating may occur for a considerably shorter time. Nevertheless, the interval between ovulations found in the present study would appear to be of insufficient duration to account for the ram fertility effect.

We thank Mrs S. H. Rowe, Mr A. Barnes, Mr S. J. Blaich and Mr P. R. Lynch for technical assistance.

\section{References}

Boshoff, D.A., van Niekerk, C.H. \& Morgenthal, J.C. (1973) Time of ovulations in the Karakul ewe following synchronisation of oestrus. S. Afr.J. Anim. Sci. 3, 13-17.

Bradford, G.E. (1972) Genetic control of litter size in sheep. J. Reprod. Fert., Suppl. 15, 23-41.

Cahill, L.P., Buckmaster, J.M., Cumming, I.A., Parr, R.A. \& Williams, A.H. (1974) The effect of the presence of a ram on the time of ovulation in ewes. $J$. Reprod. Fert. 40, 475-77.
Clarke, J.N. (1972) Current levels of performance in the Ruakura fertility flock of Romney sheep. Proc. N. Z. Soc. Anim. Prod. 32, 99-111.

Cognié, Y., Mariana, J.-C. \& Thimonier, J. (1970) Etude du moment d'ovulation chez la brebis normale ou traitée par un progestagène associè ou non a une injection de PMSG. Annls Biol. anim. Biochim. Biophys. 10, 15-24.

Cumming, I.A., Buckmaster, J.M., Blockey, M.A. de B, Goding, J.R., Winfield, C.G. \& Baxter, R.W. (1973)

Downloaded from Bioscientifica.com at $04 / 26 / 2023$ 11:13:56AM 
Constancy of interval between Luteinising Hormone release and ovulation in the ewe. Biol. Reprod. 9, 24-29.

Dauzier, L. \& Wintenberger, S. (1952) Recherches sur la fécondation chez les mammifères: durée du pouvoir fécondant des spermatozoides de bélier dans le tractus génital de la brebis et durée de la période de fécondite de l'oeuf après l'ovulation. C. r. Séanc. Soc. Biol. 146, 660-663.

Finney, D.J. (1952) Probit Analysis, 2nd edn. Cambridge University Press.

Gréen, W.W. (1947) Duration of sperm fertility in the ewe. Am. J. vet. Res. 8, 299-300.

Hight, G.K., Gibson, A.E., Wilson, D.A. \& Guy, P.L. (1975) The Waihora sheep improvement programme. Sheepfarming Annual, Massey University, pp. 67-89.

Holst, P.J. \& Braden, A.W.H. (1972) Ovum transport in the ewe. Aust. J. biol. Sci. 25, 167-173.

Lopyrin, A.I. (1971) The Biology of the Reproduction of Sheep, pp. 27-28. 'Kolos' Publ. House, Moscow.

Mackenzie, A.J. \& Edey, T.N. (1975) The fate of large 'cystic' ovarian follicles in sheep. J. Reprod. Fert. 43, 393-394, Abstr.

McKenzie, F.F. \& Terrill, C.E. (1937) Estrus, ovulation and related phenomena in the ewe. Res. Bull. Univ. Mo. Agric. Exp. Stn, 264.

Moore, N.W., Rowson, L.E.A. \& Short, R.V. (1960) Egg transfer in sheep. Factors affecting the survival and development of transferred eggs. J. Reprod. Fert. 1, 332-349.
Moore, R.W. \& Whyman, D. (1977) Relationship between semen traits, mating frequency and percentage of ewes lambing multiples in high fertility Romney sheep. Proc. N. Z. Soc. Anim. Prod. 37, 136-141.

Parsons, S.D., Hunter, G.L. \& Rayner, A.A. (1967) Use of probit analysis in a study of the effect of the ram on time of ovulation in the ewe. J. Reprod. Fert. 14, $71-80$.

Quinlan, J. \& Maré, G.S. (1931) The physiological changes in the ovary of the Merino sheep in South Africa and their practical application in breeding. 17th Rep. Div. vet. Serv., Onderstepoort, Un. S. Afr. p. 663 .

Schindler, H. \& Amir, D. (1972) Length of oestrus, duration of phenomena related to oestrus, and ovulation time in the local fat-tailed Awassi ewe. $J$. agric. Sci., Camb. 78, 151-156.

Smith, J.F. (1977) Estrus, ovulation and conception following timed insemination in Romney ewes treated with progestagen and gonadotropins. Theriogenology 7, 63-72.

Turner, H.N. (1969) Genetic improvement of reproduction rate in sheep. Anim. Breed. Abstr. 37, 545-563.

van der Westhuysen, J.M., van Niekerk, C.H. \& Hunter, G.L. (1970) Duration of oestrus and time of ovulation in sheep: effect of synchronisation, season and ram. Agroanimalia 2, 131-138.

Zeltobrjuh, N.A. \& Rak, L.P. (1964) Biological stimulation of the reproductive functions of the ewe. Ovcevodstro 10, 8-11. 